\title{
FEMINIST RIGHTS EQUALITY EDUCATION AND OCCUPATION AS SEEN IN MAYA ANGELOU'S POEMS
}

\author{
DERIK TRI FERNANDES ${ }^{1}$ \\ RAFLIS $^{2}$ \\ FETRI RENI ${ }^{3}$
}

Volume 1 Nomor 1

JILP

ISSN: 2581-0804

E-ISSN: 2581-1819

\begin{abstract}
The problem in this thesis is feminism in education, occupation and social as seen in Maya Angelou's poems. Feminism is the struggle of movement women rights in economic, education, occupation, politic, social and different culture with men. In these poems, having the theme like struggle rights of women, women rights in selfconfidence, hidden beauty, although the skills of her own feels more superior than men

The finding in this analysis is 1).

Angelou wants to voice the women must be more educated that can stand in patriarchal society, in basically women must get the rights equality in education like men. 2). Angelou wants to voice the women must get rights equality in occupation, like equality wages between men and women. 3). Angelou wants to voice nobody can do insult in physical or non-physical. In basically, degree of human its same front of Allah and society.
\end{abstract}

Keyword: feminism, rights, superior, patriarchal and equality

\begin{abstract}
ABSTRAK
Permasalahan dalam skripsi ini adalah feminisme di bidang pendidikan, pekerjaan dan sosial yang tergambar melalui lima puisi karya Maya Angelou. Feminisme merupakan aliran yang memperjuangkan hak-hak kaum perempuan di bidang ekonomi, pendidikan, pekerjaan, politik, sosial dan budaya yang berbeda dengan kaum laki-laki. Puisi Maya Angelou sendiri memiliki tema perjuangan kesetaraan hak-hak kaum perempuan melalui kepercayaan diri, kepribadian yang baik, kecantikan yang tersembunyi, maupun kemampuan-kemampuan lain yang mereka miliki yang dapat membuat mereka merasa lebih superior dibandingkan

Temuan dalam penulisan skripsi ini adalah 1).Angelou menyuarakan bahwa perempuan harus dididik agar mampu bersaing dalam masyarakat patriarkal, yang pada dasarnya hak perempuan untuk mendapatkan pendidikan itu sama dengan hak laki-laki. 2).Angelou menyuarakan bahwa perempuan harus mendapatkan hak yang sama di bidang pekerjaan, seperti kesetaraan gaji antara perempuan dan laki-laki. 3).Angelou menyuarakan bahwa perempuan tidak boleh dilecehkan dalam masyarakat, baik fisik maupun non-fisik. Pada dasarnya, derajat manusia itu sama di hadapan Allah dan masyarakat.
\end{abstract} kaum laki-laki.

Kata-kunci: feminisme, hak, superior, patriarkal dan kesetaraan 


\section{BACKGROUND OF THE PROBLEM}

Literature is a term that does not have universally accepted definition, which has variably included all written work writing processes literary value and language that foregrounds literariness, as opposed to ordinary language. Literature can be classified according to whether it is fiction or non-fiction and whether it is poetry or prose it can be further distinguished according to major forms such as the novel, short story or drama and works are often categorized according to historical periods, or according to their adherence to certain aesthetic features or expectations. Literature represents a language or a people culture and tradition. Literature is more important than just a historical or cultural artifact. Literature introduces us to new worlds of experience. We learn about books and literature, we enjoy the comedies and the tragedies of poems, stories and we may even grow and evolve through our literary journey with books.

The major of literature include prose, poetry and drama. The writer will explain about poetry. Poetry is used to achieve this artistic expression in several ways. There are certain forms and patterns that poets follow in the composition process of their work. These different forms were birthed out separate artistic and cultural movements. Most of these forms coincide with the previously mentioned definition of poetry and the most popular of these forms are elegy, narrative, ode, ballad, sonnet, villanelle, sestina, free verse, and epic (Miller, 1981:39).

Poetry is a part of literature, sometimes can be as art. Exactly, the art is to convey some words with non-literal way. The beauty of poetry be made one with honestly. Majority, honestly poetry was born from oppressed people. Therefore, the poem from oppressed people is beauty poetry because he can make a literary work in oppressed situation.

\section{PURPOSE OF THE RESEARCH}

The purpose of the research refers to the exposure of analysis provided in the limitation of the problems, this research basically has to conduct the following term:

1. To explain feminist rights equality in education that can be found in the poems
The poetry that the writer to analyze is literary works by Maya Angelou, because the writer thinks that Maya Angelou poems are interesting and give inspiration can be found of her poems, she wants to voice about rights equality in our life. Nobody can do discrimination to women, like social, education and occupation. Angelou has so many works, like poem, book and as civil rights activist. The writer feeling amazed to analyze Maya Angelou's poems because she is the famous and influence woman in United States America. Maya Angelou is an African-American poet, novelist, educator, dramatist, actress, producer, film maker and civil rights activist. Maya Angelou write poems about segregation and discrimination toward African-American in the United States and some of her poems talk about identity and the issue of racism. From some of her poems the writer takes five interesting poem about feminist. These poems are; Still I Rise, Men, Phenomenal Woman, Woman Work and Equality. In her poems, Angelou depicts the daily work of a woman in the Southern States of America 1960s-1970s. Therefore, the writer chooses "Feminist Rights Equality Education and Occupation as Seen in Maya Angelou's Poems" as the title of analysis.

Formulation of the Problem

From the problems of limitation, the writer divides the problem into three analysis questions:

1. What are feminist rights equality in education that can be found in the poems?

2. What are feminist rights equality in occupation that can be found in the poems?

3. What are the feminist rights equality in the social that can be found in the poems?

2. To explain feminist rights equality in occupation that can be found in the poems

3. To explain feminist rights equality in social that can be found in the poems

Significances of the Research 
Significances of the research are to add literary study in term of extrinsic side feminist analysis from Maya Angelou's poems: Still I Rise, Men, Phenomenal Woman, Woman Work and Equality. Then, the finding in this research is hopefully useful as the information whoever interested in understanding literary study that focuses extrinsic feminist analysis. The writer also hopes this analysis can become the guidance for next researchers to conduct further analysis.

For the students this analysis is hopefully as the information whoever interested in understanding literary. Finally, the writer also hopes that this writing will give the contribution to the English Department students and whoever may be interested in the subject being discussed.

Theoretical Framework

Feminist can be used to describe a political, cultural or economic movement aimed at establishing equal rights and legal protection for women. Feminism involves political and sociological theories and philosophies concerned with issues of gender difference.

The writer describe about rights equality, this term can be used about ensuring that every individual has an equal opportunity to make the most of their lives and talents and believing that no one should have poorer life chances because of where, what or whom they were born, what they believe or whether they have a disability. Equality recognizes that historically, certain groups of people with particular characteristics like race, disability, sex and sexuality, have experience discrimination.

According to Mary Wollstonecraft (1792:189), feminism is a cultural as well as a political movement. Feminist movements have campaigned for women rights, including the right to vote, to hold public office, to work, to earn fair wages or equal pay, to own property, to receive education, to enter contracts, to have equal rights within marriage, and to have maternity leave.

The writer uses Feminist approach advocating equal rights for women in a political, economic, social, psychological, personal and aesthetic sense. On the thematic level, the feminist reader should identify with female characters and their concerns. The object is to provide a critique of assumptions and an analysis of patriarchal visions or ideologies inscribed in a literature that is male centered and male dominated.

In this research the writer uses theory Second Wave Feminism refers to the period of activity in the early 1960s and lasting through the late 1980s. The second wave feminism focus on movements to voice rights equality. The consequences are inequality in social make the woman and man separate with class social, inequality in occupation make a woman get a lower wages than man in a company and inequality education the woman cannot develop herself because of limitation of study knowledge. Review on Related Theory

The term feminism can be used to describe a political, cultural or economic movement aimed at establishing equal rights and legal protection for women. Feminism involves political and sociological theories and philosophies concerned with issues of gender difference, as well as a movement that advocates gender equality for women and campaigns for women's rights and interests. Although the terms "feminism" and "feminist" did not gain widespread use until the 1970s, they were already being used in the public parlance much earlier; for instance, Katherine Hepburn speaks of the "feminist movement" in the 1942 film Woman of the Year.

According to Maggie Humm and Rebecca Walker, the history of feminism can be divided into three waves. The first feminist wave was in the nineteenth and early twentieth century, the second was in the 1960s and 1970s, and the third extends from the 1990s to the present. Feminist theory emerged from these feminist movements. It is manifest in a variety of disciplines such as feminist geography, feminist history and feminist literary approach.

Feminism has altered predominant perspectives in a wide range of areas within Western society, ranging from culture to law. Feminist activists have campaigned for women's legal rights (rights of contract, property rights, voting rights); for women's right to bodily integrity and autonomy, for abortion rights, and for reproductive rights (including access to contraception and quality prenatal care); for protection of women and girls from domestic violence, sexual harassment and rape; for workplace rights, including maternity leave and equal pay; against misogyny; and against other forms of gender-specific discrimination against women.

During much of its history, most feminist movements and theories had leaders who were predominantly middle-class white women from Western Europe and North America. However, at least since Sojourner Truth's 1851 speech to American feminists, women of other races have 
proposed alternative feminisms. This trend accelerated in the 1960s with the Civil Rights movement in the United States and the collapse of European colonialism in Africa, the Caribbean, parts of Latin America and Southeast Asia. Since that time, women in former European colonies and the Third World have proposed "Post-colonial" and "Third World" feminisms. Some Postcolonial Feminists, such as Chandra Talpade Mohanty, are critical of Western feminism for being ethnocentric. Black feminists, such as Angela Davis and Alice Walker, share this view.

In the history of feminism, Simone de Beauvoir wrote that "the first time we see a woman take up her pen in defense of her sex" was Christine de Pizan who wrote Epitre au Dieu d'Amour (Epistle to the God of Love) in the 15th century. Heinrich Cornelius Agrippa and Modesta di Pozzo di Forzi worked in the 16th century. Marie Le Jars de Gournay, Anne Bradstreet and Francois Poullain de la Barre wrote during the 17 th.

Feminists and scholars have divided the movement's history into three "waves". The first wave refers mainly to women's suffrage movements of the nineteenth and early twentieth century's (mainly concerned with women's right to vote). The second wave refers to the ideas and actions associated with the women's liberation movement beginning in the 1960s (which campaigned for legal and social rights for women). The third wave refers to a continuation of, and a reaction to the perceived failures of, second-wave feminism, beginning in the 1990s.

First-wave feminism refers to an extended period of feminist activity during the nineteenth century and early twentieth century in the United Kingdom and the United States. Originally it focused on the promotion of equal contract and property rights for women and the opposition to chattel marriage and ownership of married women (and their children) by their husbands. However, by the end of the nineteenth century, activism focused primarily on gaining political power, particularly the right of women's suffrage. Yet, feminists such as Voltairine de Cleyre and Margaret Sanger were still active in campaigning for women's sexual, reproductive, and economic rights at this time. In 1854, Florence Nightingale established female nurses as adjuncts to the military.

In Britain the Suffragettes and, possibly more effectively, the Suffragists campaigned for the women's vote. In 1918 the Representation of the People Act 1918 was passed granting the vote to women over the age of 30 who owned houses. In 1928 this was extended to all women over twenty-one. In the United States, leaders of this movement included Lucretia Mott, Lucy Stone, Elizabeth Cady Stanton, and Susan B. Anthony, who each campaigned for the abolition of slavery prior to championing women's right to vote; all were strongly influenced by Quaker thought. American first-wave feminism involved a wide range of women. Some, such as Frances Willard, belonged to conservative Christian groups such as the Woman's Christian Temperance Union. Others, such as Matilda Joslyn Gage, were more radical, and expressed themselves within the National Woman Suffrage Association or individually. American first-wave feminism is considered to have ended with the passage of the Nineteenth Amendment to the United States Constitution (1919), granting women the right to vote in all states.

Then, second-wave feminism refers to the period of activity in the early 1960s and lasting through the late 1980s. The scholar Imelda Whelehan suggests that the second wave was a continuation of the earlier phase of feminism involving the suffragettes in the UK and USA. Second-wave feminism has continued to exist since that time and coexists with what is termed third-wave feminism. The scholar Estelle Freedman compares first and second-wave feminism saying that the first wave focused on rights such as suffrage, whereas the second wave was largely concerned with other issues of equality, such as ending discrimination.

The feminist activist and author Carol Hanisch coined the slogan "The Personal is Political" which became synonymous with the second wave. Second-wave feminists saw women's cultural and political inequalities as inextricably linked and encouraged women to understand aspects of their personal lives as deeply politicized and as reflecting sexist power structures.

Finally, the third-wave feminism began in the early 1990s, arising as a response to perceived failures of the second wave and also as a response to the backlash against initiatives and movements created by the second wave. Thirdwave feminism seeks to challenge or avoid what it deems the second wave's essentialist definitions of femininity, which (according to them) over-emphasize the experiences of upper middle-class white women. 
A post-structuralist interpretation of gender and sexuality is central to much of the third wave's ideology. Third-wave feminists often focus on "micro-politics" and challenge the second wave's paradigm as to what is, or is not, good for females. The third wave has its origins in the mid-1980s. Feminist leaders rooted in the second wave like Gloria Anzaldua, bell hooks, Chela Sandoval, Cherrie Moraga, Audre Lorde, Maxine Hong Kingston, and many other black feminists, sought to negotiate a space within feminist thought for consideration of race-related subjectivities.

Third-wave feminism also contains internal debates between difference feminists such as the psychologist Carol Gilligan (who believes that there are important differences between the sexes) and those who believe that there are no inherent differences between the sexes and contend that gender roles are due to social conditioning.

Fakih in Analisis Gender dan Transformasi Sosial (Fakih, 2008:77) states:

Pekerjaan yang dianggap sebagai pekerjaan perempuan seperti guru taman kanak-kanak atau sekretaris, yang dinilai lebih rendah dibanding pekerjaan lakilaki dan seringkali berpengaruh terhadap perbedaan gaji antara kedua jenis pekerjaan tersebut.

Occupation reputed as woman occupation like the kindergarten teacher or secretary, have a lower value than man occupation and always influence concerning about differential of wages both of these occupation (translated by writer).

Fakih in Analisis Gender dan Transformasi Sosial (Fakih, 2008:83) states:

Pada umumnya mereka
mengakui bahwa feminisme
merupakan gerakan yang
berangkat dari asumsi
kesadaran bahwa kaum
perempuan pada dasarnya
ditindas dan dieksploitasi,
serta harus ada upaya
mengakhiri penindasan dan
pengeksploitasian tersebut.

In generally they are recognize the feminism is movement from realization of assumption basically that woman suppressed and exploitation, therefore struggle to stopped up the oppression and exploitation (translated by writer)

In analyzing Maya Angelou's poems: Still I Rise, Men, Phenomenal Woman, Woman Work and Equality. The writer needs systematic ways to write this research, which are initially begun with the method of collecting the data, method of analyzing the data, technique of collecting the data and then continued with the technique of analyzing the data.

Method of Collecting the Data

In collecting the data, the writer uses library research. This research is oriented in the library in order to find the related data, however it is not restricted in finding other written material from internet or even from the motion picture. According to Pradopo (2001:23), Penelitian sastra dijadikan sebuah observasi yang dilakukam di perpustakaan, yang mana penulis memperoleh data dan informasi tentang obyek puisi tersebut.

A library is a collection of sources of information and similar resources, made accessible to a defined community for reference or borrowing. It provides physical or digital access to material, and may be a physical building or room, or a virtual space, or both. A library's collection can include books, periodicals, newspapers, manuscripts, films, maps, prints, documents, microform, CDs, cassettes, videotapes, DVDs, Blue-ray Discs, ebooks, audio books, databases, and other formats.

Activity of data collection is a very important part in any form of research. In this study, the writer uses documentation. The method of documentation is to find data about the things or variables in the form of notes, transcripts, books, newspapers, magazines, inscriptions, minutes of meetings, agendas, and so forth, (Arikunto, 2006: 231). The instrument of this study is the writer. The writer is as the key or main instrument that spent a deal great or time reading and understanding the poems of Maya Angelou. 


\section{METHOD OF ANALYZING THE DATA}

In analyzing the data, the information from data collection is processed and presented in form of thesis. In the application, the writer uses dynamic structuralism method.

Dynamic structuralism is a general approach to development that views psychological structure as the dynamic organization of self-constructed, socially embedded skills and activities (actions and thoughts): This framework, and its tools, applies to both long-term development and short-term micro development (building of dynamic structures and skills), Variability is the norm, not the exception, Focuses simultaneously on variability and stability (Pradopo, 2001:69).

Etymologically, structure came from word, structura (Latin), means form or building. Structuralism is an understanding of elements of the structure itself with mechanism of interrelation, the interrelation of one element with the others, and the interrelation of one element with the totality. Dynamic structuralism was first found by Mukarovsky and Felik Vodicka. They said that literary works are the process of communication, fact of semiotic, consists of sign, structure, and values.

Definitively, structuralism gives attention to the analysis of elements in literary works. The elements of prose are theme, conflict, setting, characters, plot, point of view, and style of language. Elements in poetry are theme, stylist, imaginary, rhyme, diction, symbol, etc. Elements in Drama are theme, dialog, conflict, setting, character, plot, and style of language.

Technique of Collecting the Data

The writer uses documentary technique in collecting the data. This technique is attempted to trace the source of information in the form of document which are relevant to the object of the research. The writer uses reading the books and searching on internet for collecting the data.

The data of this study are taken from the five poems written by Maya Angelou. In collecting data, the writer took the following theory Miller (1981:128) how to interpret poetry steps:

3. The writer determines theme in five Maya Angelou's poems.
4. The writer determines tone of poems

5. The writer determines techniques are used in the poem

Technique of Analyzing the Data

Data analysis is a time-consuming and difficult process, because typically the researcher faces massive amounts of field notes, interview transcripts, reflections, and information from documents to examine and interpret, (Ary, 2002: 465). Data analysis is the process of systematically searching and arranging the interview transcripts, field notes, and other materials that the researcher accumulate to increase her own understanding.

To answer the research problem, after the data have been collected, the writer analyzed them systematically. The writer conducted the analysis through some steps as follow:

4. Reading the whole poems to find the meaning

After identifying in the poems, then the writer categorizes them into some of rights equality education, social and occupation.

5. Interpreting poems to find general meaning and detail meaning the poems

To identifying the meaning of the poems, the writer reads every stanza of poems to understand the meaning content of poems. The writer studies the general meaning and detail meaning by identifying the lexical meaning and contextual meaning of the poems. After that the writer tries to find out the meaning of the poems.

6. Finding the theme of the poems

To find the theme of the poems, first of all, the writer finds the general meaning and the detail meaning of poems. After that the writer starts finding thoughts being expressed in the poems to describe the theme of the poems.

7. Making conclusion

After the writer finds the answer from the research problem, then the writer makes the conclusion of the analyzed data. 


\section{ANALYSIS AND FINDING}

\section{Educational Aspect}

The writer finds educational aspect in the Maya Angelou's poems "Men" to analyze in this chapter and explain the meaning of this verse.

As men walked up and down the street. Wino men, old men.

Young men sharp as mustard.

See them. Men are always

Going somewhere.

In this verse, "As men walked up and down the street" Maya Angelou tries to voice the man can go somewhere wherever he wants, "young men sharp as mustard" the men are like mustard, mustard is the cooking spices useful when some people cooking some food. Its mean men are the useful than women in this world, so Angelou wants to voice the women is more educated in this era.

Angelou hopes the women in this world have enthusiastic for the education, because she believes more education it same like she gets more respect from the men. Education is the symbol of respect someone to us and Angelou hopes no country in the world to do a discrimination to women in education, because the men and women needs the education until she or he grows old. In the case, society thinks about education just for men and women to be a housewife

Occupational Aspect

The writer finds occupational aspect in the Maya Angelou's poem "Still I Rise" to analyze in this chapter and explain the meaning of this verse.

You may shoot me with your words,

You may cut me with your eyes,

You may kill me with your hatefulness,

But still, like air, I'll rise

In this verse "Still I rise" poem, Maya Angelou voice the women are the strong human because when the men insult, sarcastic view, hatefulness to me and she said still like air I will rise. In another side, the men feels the women cannot be a leader, because she is the weak person its mean she cannot control or manage a business with the reason is very difficult to approve this reality. It is obvious that with the same abilities, women can manage the same businesses that men do.

In this reality, the women cannot reach the top of career in the world. Majority, when her ages more than 40 years old she feels bored about this job after that the problem is resign the job in a company. So this problem has two side, the first still working is relevant with feminist in occupational and the second resign the job make the women feel oppression cause she doing the bored routine as housewife. Angelou hopes the women must get a job in a company or government do not hear the words by the men.

That I dance like I've got diamonds

At the meeting of my thighs?

In this verse, Angelou said in Still I Rise poem "That I dance like I've got diamonds" I can get a material or money "At the meeting of my thighs" its mean when my thighs are closed or without open my thighs. Angelou wants to voice the women can get a material or money without join with group prostitution, many more a good job be sides that, although Angelou even spending two years working as a prostitute.

The material or money from prostitution cannot hold on long time, because it's the forbidden thing. So doing a useful thing to everybody and women must get honorable job in order to stop get an abuse for men. The writer believes in occupational aspect, man and woman are equal. Do not to be a segregation person, human is equal.

I'm not cute or built to suit a fashion model's size

But when I start to tell them,

They think I'm telling lies

In this verse "Phenomenal Woman" poem. Maya Angelou tries to voice it is better to be model with a relevant wages than worker, because $19^{\text {th }}$ centuries in America wages of woman and man are different. Man gets a wages $\$ 1.08$ each day and woman get $\$ 0.63$ its mean inequality occupation in a company, but actually the case is intensity and duration this job just same like men.

Why woman get a different wage? In $19^{\text {th }}$ centuries, usually woman just stay in home and the woman tries begin work like man. In the case, Lowell factory at Massachusetts have 66.000 women worker, 24.000 boys worker and 10.000 men worker. Average, the women workers are ordered by her father (immigrant) because the father cannot fulfill of daily life.

Therefore, with this bad economy condition so many women want to be a worker with the two factors; the agriculture effort is 
bankrupt and do not have money to continue education. Some of women want to be a worker with the reason to defray continue education her brother for the brighter future. In the initial $18^{\text {th }}$ century, the women try to be a teacher. If we compare woman and man teacher are 1:4 and the end of $18^{\text {th }}$ century 3:4. Woman wants to be participation in occupation another of housewife.

I've got the children to tend

The clothes to mend

The floor to mop

The food to shop

Then the chicken to fry

The baby to dry

I got company to feed

The garden to weed

In this verse "Woman Work" poem. Maya Angelou tries to voice the women must have a job to fulfill the daily life. The women are not to trade on her husband, so many needed must fulfill every day like buying foods, chicken, drink for baby and task of housewife like to tend the children, to mend the clothes, to mop the floor and to weed the garden. Angelou believes the woman can do anything in home and outside, you are the strong woman.

\section{Social Aspect}

The writer finds social aspect in the "Still I Rise" Maya Angelou's poems to analyze in this chapter and explain the meaning of this verse.

You may trod me, in very dirt

But still, like dust, I'll rise.

In this verse "Still I rise" poem, "You may trod me, in very dirt But still, like dust, I'll rise" This tells us that no matter what happens, I will rise when the men think women like dust. This feel insult me in social, kick the women in social life. Angelou wants to voice nobody can do discrimination gender in society, man and women are equal. In this world human have equal position. She believes that women should enjoy social, legal, and intellectual equality with men.

You may shoot me with your words,

You may cut me with your eyes,

You may kill me with your hatefulness,

But still, like air, I'll rise

In this verse "Still I rise" poem, Maya Angelou voice the women are the strong human because when the men insult, sarcastic view, hatefulness to me in society and she said still like air I will rise. She feels subordinate by men in society, no matter what happened I will rise. The men think women cannot do more than those men do, it means superior and inferior in society. Men and women are equal in society, because men do not have rights to insult the women.

That I dance like I've got diamonds

At the meeting of my thighs?

In this verse, Angelou said in Still I Rise poem "That I dance like I've got diamonds" I can get a material or money "At the meeting of my thighs" it means when my thighs are closed or without open my thighs. Angelou wants to voice the women can get a material or money without join with group prostitution, many more a good job be sides that. The material or money from prostitution cannot hold on long time, because it's the forbidden thing. So doing a useful thing to everybody and women must get honorable job in order to stop get an abuse for men. The women must be a better person in social with the better chooses.

I am the dream and the hope of the slave

In this verse, Angelou said in Still I Rise poem "I am the dream and the hope of the slave" Angelou wants to voice I will smash the slavery in the world, I am the activist human rights. In the art way, Angelou wants the slavery will be completely remove in this world because the slave is unconstitutional with our rights in society. I will completely remove the slavery with my way and feminism fighting for to let the world see and accept women from all walks of life and all manners of backgrounds as equal human.

Their shoulders high like the

Breast of a young girl

In this verse, Angelou says in Men poem "Their shoulders high like the Breast of a young girl. Angelou wants to voice social men and women are equal position. The men have a strong shoulder for hard worker and men has breasts to give suck they children. Women are not subordinate by men. Angelou tries to play a metaphor compare shoulder and breast. The writer likes this verse, because it is very honest and natural verse.

Then they swarm around me,

A hive of honey bees.

In this verse, Angelou says in Phenomenal Woman poem "Then they swarm around me, A hive of honey bees" Angelou wants to voice in her poem, the men must protect women like bees swarm around hive, do not each time humiliate me. When seven years old, Angelou is used to be raped by her mother's 
boyfriend. Angelou wants to inveigh the actions like raped or sexuality abuse. Rape or sexuality abused is unconstitutional action.

Rape is a type of sexual assault usually involving sexual intercourse, which is initiated by one or more persons against another person without that person's consent. Feminists view rape as an action that humiliates a woman's dignity. Nevertheless, feminism generally brings about the world in which people of all ages and both sexes embrace full responsibility for their action. It teaches that women are not slaves to men. Our bodies are our most precious material possession and we will only have one body. We deserve to have that body respected by others. This means that bad treatments, which are often committed toward women, such as oppression, rape, and other forms of sexual harassment, are unacceptable.

Women are unconscious that they have been trapped by male's definition of what a woman is. Women have been brainwashed by the stereotype of strong men and feeble women. Some feminists say that the existence of women's writing tends to undermine the authority of male's discourse. Female sexuality is revolutionary, subversive, heterogeneous and open, and if there is a female principle, it should remain outside the male's definition of the female.

You announce my ways are wanton, that I fly from man to man, but if I'm just a shadow to you, could you ever understand?

The use of the word "wanton," along with the common expression of moving "from man to man" suggests that the speaker is a prostitute, or can be compared to one in their personal life. Interestingly, the accusation is not denied, but rather is met with another accusation from the narrator: that someone who judges them for the things they do someone who could not understand being in a position to do them.

The language is used here is powerful. The speaker describes their own self as being "a shadow" in the eyes of their accuser, suggesting that they are beneath them in their social hierarchy. However, they follow up this observation by pointing out that because of this metaphorical distance between the two, the accuser cannot possibly understand their own accusation. In a way, the speaker is placed above the accuser not by denying their words, but by defending their actions. Angelou wants to voice an equally in social man and woman.

Conclusions

Since of $19^{\text {th }}$ centuries, women in America got the inequality treatment like educational, occupational and social aspect. Therefore, Maya Angelou wants to voice rights equality women and men by means of literature work. Maya Angelou persevering give voice gender equality, because discrimination against women still happen.

The principles basic feminist is existence of degree equality between women and men front of Allah and society. Thus, sex and gender are main idea of feminist in basically different of men and women are representative by two concepts that is sex and gender. After analyzing the five of Maya Angelou poems, Angelou shares the same theme in the five poems that is oppression gender should struggle to voice rights equality from male dominant. Maya Angelou hopes all of women enthusiast mixed up in education. Man and woman are equal concerning rights equality in education.

The writer finds of purpose Angelou in her poems. Besides of woman of letters, Angelou is human rights activist. She wants to voice human rights from her literature work. Angelou wants to completely remove the slavery in the world, especially in America. Rights equality from the wages when she was to be a worker in a company, do not insult women to be a leader in her career journey.

Men and women are equal in society, because men do not have rights to insult the women. The principles basic feminist is existence of degree equality between women and men front of Allah and society

Only when woman and man are equally free, and woman and man are equally dutiful in exercise of their responsibilities to family and state, can there be true freedom and female writers can insert and explore issues of women's equality, women's status, women's rights and the role of public or private, political or domestic life in their literary works.

Suggestions

In this sub chapter, the writer gives the three suggestions to other researchers, the readers and the students

\section{Other researchers}

There are still many aspects which can be analyzed about poetry and feminist movement. Finally, other researchers can analyze other aspect in feminist of English Literature and the result of this study may be used as early 
information to conduct further researchers.

2. The readers

The writer expects that the readers are eager to study about literature, especially understanding the poetry. The writer hopes that the readers can be know about the purpose of feminist movements and apply that in their life.
The writer also hopes this thesis enrich the reader's knowledge about theory of literature.

3. The Students

The student need to enrich knowledge about feminist and poetry, they also need to increase motivation and interest to learn about English Literature such as poetry. 


\section{Bibliography}

Arikunto, Suharsimi. 2006. Prosedur Penelitian Suatu Pendekatan Praktik. Jakarta: PT Rineka Cipta.

Ary, Donald. 2002. Introduction to Research in Education. USA: Wadsworth.

Chodorow, Nancy J. 1991. Feminist Theory. Retrieved from the website: https://en.wikipedia.org/wiki/Feminist_th eory on November 8th, 2016 at 4:43 PM

Fakih, Mansour.2008. Analisis Gender dan Transformasi Sosial. Yogyakarta: Insist Press

Hawkesworth, Mary E. 2006. History and Theory of Feminism. Retrieved from the website: http://www.gender.cawaterinfo.net/knowledge_base/rubricator/ feminism_e.htm on November 8th, 2016 at 4:43 PM.

Miller, Ruth and Robert A. Greenberg. 1981. Poetry: An Introduction. New York: St Martin's Press

Monroe, Harriet. 2016. Maya Angelou 19282014. Retrieved from the website: https://www.poetryfoundation.org/poems- and-poets/poets/detail/maya-angelou on November 8th, 2016 at 4:43 PM.

Plain, Gill and Sellers, Susan. 2007. A History of Feminist Literary Criticism. Cambridge University Press.

Pradopo, Rachmat Djoko, et.al. 2001. Metodologi Penelitian Sastra. Yogyakarta: PT. Hanindita Graha Widia.

Showalter, Elaine. 1977. A Literature of Their Own. London: Princeton University Press.

Sylvan Barret, Marton Berman, William Burto.1989. An Introduction to Literature. Ninth Edition. London: Scott, Foresman and Company.

Tyson, Lois. 2006. Critical Theory Today. A User-friendly Guide New York: Routledge

Wellek, Rene and Austin Warren. 1996. Theory of Literature. New York: Harcourt Brace and World Inc.

Wollstonecraft, Mary. 1792. A Vindication of The Rights of Woman. Boston. Cambridge University Press. 